\title{
The Impact of Qualified Foreign Institutional Investors on Controlling Shareholder's Tunneling: Evidence of Listed Companies in China
}

\author{
Zhenyu Li \\ Department of Finance, Jinan University, Guangzhou, China \\ Email: zhenyu_lee@foxmail.com
}

How to cite this paper: Li, Z.Y. (2017) The Impact of Qualified Foreign Institutional Investors on Controlling Shareholder's Tunneling: Evidence of Listed Companies in China. American Journal of Industrial and Business Management, 7, 522-536. https://doi.org/10.4236/ajibm.2017.74038

Received: March 13, 2017

Accepted: April 27, 2017

Published: April 30, 2017

Copyright $\odot 2017$ by author and Scientific Research Publishing Inc. This work is licensed under the Creative Commons Attribution International License (CC BY 4.0).

http://creativecommons.org/licenses/by/4.0/

\begin{abstract}
Based on the data of the listed companies of Shanghai Stock Exchange and Shenzhen Stock Exchange from 2012 to 2015, we studied the impact of qualified foreign institutional investors (QFII) on the tunneling of listed companies' major shareholders. The results show that QFII can effectively control the behavior of tunneling of the substantial shareholder of listed companies, and the inhibitory effects are different in the different ownership companies. QFII can inhibit the behavior of tunneling of the substantial shareholder of state-owned enterprises and private enterprises, and the inhibition effect is better in private enterprises. However, there is no inhibition effect on the behavior of tunneling of the substantial shareholder of foreign-funded enterprises.
\end{abstract}

\section{Keywords}

QFII, Tunneling, Corporate Governance

\section{Introduction}

When the capital flow is extremely unstable, the imperfection of the financial system is more obvious. Due to the development of the Chinese capital market being not mature enough, the risk of direct open is great. During a very long period, China can not realize the freely convertible of RMB and completely open of capital account. Therefore, in order to introduction of foreign investment moderately and open the capital markets gradually, we introduced the transitional policy: qualified foreign institutional investors (QFII). Qualified Foreign Institutional Investor (QFII) system is a kind of institutional arrangement that China 
using to introduce the foreign capital selectively and limitedly in the A-share market under the background of capital projects not completely open. It is an important measure of China's stock market to expand the opening up. According to the regulations of transitional policy, QFII can exchange the host country's currency into RMB by means of exchange, then investing on Chinese market from the special account which established on China. Until the end of 2016, there is a total of 304 QFII approved by China, the quantity of A share account of QFII reached 1071, and the State Administration of Foreign Exchange has approved 873.09 billion dollars on QFII investment. On the market downturn in 2016, QFII still made a large number of researches on the listed companies of China. QFII has researched 123 companies up to 355 times only in the fourth quarter. This can be described as very different with the domestic institutional investors hesitated. However, the phenomenon of "one share being overwhelmingly big" exists in the listed companies universally in China, and the situation of big shareholders infringes on small and medium shareholders usually appeared. In addition, QFII can bring money to the listed company, whether it can play a supervisory role on big shareholders infringe on small and medium shareholders? If it can control effectively, is it different in different ownership listed companies? This article, based on the theoretical and empirical analysis, against this question, studies the effect of QFII on shareholder's tunneling in the listed companies. We wish to provide theoretical basis for QFII control substantial shareholders' tunneling. It is of great practical significance to study this problem to improve the governance mechanism of listed companies, to effectively protect the interests of small and medium shareholders, to promote the healthy development of listed companies and capital markets, and to further improve the QFII system. At the same time, through the study of this issue, we explain the behavior of institutional investors, especially QFII and its internal corporate governance mechanism, revealing the process and mechanism of QFII in the suppression of large shareholders' tunneling, which has a certain theoretical value.

\section{Literature Review}

\subsection{Institutional Investors and Tunneling}

In the 19th century, institutional investors began to appear, and now institutional investors continue to develop. More and more institutional investors participate in corporate governance actively. Hartzell and Starks found that the higher the proportion of institutional investors, the more likely they could be secured, the more proceeds that would be monitored, and the more willing institutional investors were to participate in corporate governance. In addition, the concentration of ownership also determines the ability of such investors to participate in the management of the company. Institutional investors with higher proportion were more able to join forces competition for proxy voting rights to achieve the supervision of company "insider" [1]. Smith argued that external independence makes it possible for institutional investors to make up for deficiencies in 
the internal control of largest shareholders and institutional investors become an alternative to corporate governance [2].

In addition, some scholars based on the various characteristics of the institutional investors to classify them, and then study its supervision of the behavior of major shareholders. Chen et al. classify institutional investors into two categories based on whether they have business contacts or not. One is an independent institution that does not have a business relationship with the company, which is not affected by management and has less cost of supervision. Another is a gray body with a business relationship with the company, which is vulnerable to management and has higher supervision costs [3]. Coffee, Bushee, Ramalingegowda and $\mathrm{Yu}$ divide institutional investors into short-term investors and long-term investors based on the length of their holdings. And found that generally short-term investors hold the shares of a number of companies, and the frequency of its transactions made they do not have enough time and energy to collect enough information to curb the big shareholders' tunneling. On the other hand, long-term investors generally hold the shares of a few companies, and the concentration of holdings is relatively reduce the cost of supervision, so that long-term investors have enough time and motivation to collect relevant information to participate in corporate governance. As a result they can monitor the behavior of major shareholders to reduce the damage to their interests because of major shareholders' tunneling [4] [5] [6].

Most of the existing research in domestic academics argues that institutional investors have the motivation and ability to supervise the intrusions of insiders. Tang and Yuan found that institutional investors have the power and ability to supervise the insider's encroachment of interests in order to obtain excess returns, and this is consistent with the interests of small and medium investors [7]. Zheng suggested that the invasion of small and medium-sized shareholders' interests by large shareholders can be eased relying on foreign investors. Domestic scholars also discussed the relationship between institutional investors and large shareholders' tunneling behavior according to different characteristics [8]. Yao and Liu studied the role of funds and brokers in the refinancing bill, and found that the fund in the refinancing bill have an effect on protecting the interests of small and medium investors, but the broker did not [9]. Wu et al. classified institutional speculators from the point of view of their independence and duration of holding period. It was found that institutional investors with independence have greater inhibitory effect on shareholders' tunneling and more power to supervise the tunneling of major shareholders. Further research found that institutional investors in the state-owned enterprises can monitor effectively, but in the family business is not [10].

\subsection{Researches on QFII}

Since 2003, QFII system in China has been implemented for 14 years. In the past fourteen years, domestic scholars mainly study QFII through these three aspects : QFII's holding preferences and investment characteristics, the impact of 
QFII system on the securities market, the impact of QFII system on corporate governance. Sun and Lin found that QFII has a unique investment personality in China's securities market. In the domestic market with prevalent speculation, QFII tend to frequent conversion, and prefer to invest the traditional, emerging and tertiary industry [11]. Hou compared QFII and domestic institutional investors from the four aspects of stock picking preference, trading strategy, industry strategy and independent investment. It is found that QFII tend to invest in China's traditional industries, and their investment is more concentrated, while domestic institutional investors are more inclined to the financial and insurance industry [12]. Shen and Zhu found that in the short term QFII chose the value of speculation. From market performance of the listed companies which QFII increased holdings, these listed companies quarterly rate of return significantly ahead the average rate of return of the A-share market [13]. Teng and Huang through the empirical study of the QFII holding period found performance of QFII in the past decade in A-share market did not meet the "advocacy value investment" effect, and its investments in the A-share market are mainly short-term speculation. Overall, QFII follow the basic concept of value investment, but at the same time also take speculation. And QFII incline to invest in China's traditional and advantageous industry [14].

There is no consensus on the existing research on the impact of QFII on the securities market. Some scholars believe that the introduction of foreign institutional investors will bring favorable impact on the securities market. Amita Batra studied the volatility of the stock return in India from 1979 to 2003, and found that foreign institutional investors would not have an impact on stock earnings volatility [15]. Gao insisted that QFII can bring more advanced investment management philosophy, and with the amount of investment of QFII increasing, its positive role is stronger. Some scholars also have found that the introduction of foreign institutions is not conducive to the stability of the securities market [16]. $\mathrm{Liu}, \mathrm{Hu}$, and Wang, respectively study through theoretical and empirical research and found that transactions of QFII will cause a significant flock effect [17]. Wei attributed the stock market changes one year ago to the manipulation of the four QFII institutions, and in order to call for strengthening the regulation of their trading behaviors [18].

There are few empirical studies on QFII's involvement in corporate governance. Dong and Ye found that QFII used passive investment strategy and lacked the initiative to participate in corporate governance, so its shareholding did not improve the performance of listed companies [19] [20]. Wu and Wan suggested that the holdings of QFII have a significant impact on dividend policy, and it can promote listed companies to have more cash dividends or pay more dividends [21].

In the study of institutional investors and large shareholders' tunneling, domestic and foreign scholars all have explored the wishes and effects, but domestic scholars have often adopted some specific institutions to study. On the research of QFII system, the existing literatures are divided into three aspects: 
holding preference and investment strategy, the impact on the stability of the capital market and the effect on corporate governance. In research of QFII's participation of corporate governance, most of the earlier conclusions are considered irrelevant, but in recent years the conclusions of the study has changed. Most of the early studies concluded that QFII can not improve corporate governance and its value. However, some recent studies have found that QFII holdings have a significant impact on dividend policy, and the higher the proportion of QFII shares, the better the performance of the company. It should be related to vigorously promote the development of QFII system. As in the existing research of QFII and corporate governance, the study on whether QFII can restrict the tunneling of major shareholders is rare. Therefore, this paper chooses the non-financial listed companies in the A-share market as a sample from 2012 to 2015, and divides the enterprises into three categories: state-owned enterprises, private enterprises and foreign-funded enterprises. It explores whether QFII has a significant effect on the tunneling of large shareholders and whether it plays a different role in different types of listed companies. In order to make suggestions for better introduction of foreign institutional investors, improvement of the corporate governance mechanism and protecting the interests of small and medium investors.

\section{Theoretical Analysis and Research Hypothesis}

\subsection{The Impact of QFII on Tunneling}

There are four aspects on practical reason of tunneling of the substantial shareholder existed universally in China. Firstly, the separation of two rights. The ownership of enterprise is divided into the rights of control and residual claims. In the case of the equity concentration, substantial shareholders use the structure of pyramid, cross-shareholdings and directors to each other to "move" the cash flow rights which made the rights of control separate with residual claims, and the rights of control exceed the rights of residual claims. According to the principle of majority rule on the shareholders meeting the right to vote of small shareholder is often overlooked. The decision of the company often embodies the will of the substantial shareholder, in favor of achieving maximizing the interests of substantial shareholder, but all minority shareholders undertaking the results of decision. Secondly, system problem. The relative independence of the capital of listed company of China's became weaker, because the vast majority of listed companies of A-share go public in two ways, one kind is the divestiture asset from parent company to set up, this phenomenon is commonly seen in mainland-listed companies, another one is purchasing shell corporations, this phenomenon is commonly seen private listed companies. These two kinds made a close internal connection between the listed companies and the parent companies. Thirdly, internal management defects. Shareholding concentration made the decision may pass the shareholder meeting which are bad for minority shareholders, and it is difficult to embody other shareholders' supervising function. Selection of independent directors often subjected to substantial share- 
holders control and the rate became less, independent directors are difficult to make real "independent" when making decisions. Supervising authority of the board of supervisors usually be ignored, and the finance restricted by the board of directors, so it can not play an effective supervision role. Executive basically appointed by the board of directors which represents the interests of the majority shareholders. Maybe it has a certain degree of collusion with shareholders, even to the substantial shareholders. Fourth, the lack of the protection law of small and medium investors. The provision about class action lawsuit and the burden of proof by the defense in China's laws go against maintaining their own interests of Smaller investors. And we find something is missing in the current laws on enforcement.

There are two reasons why QFII will participate in corporate governance, and checks the balances of the major shareholders. First, there is a natural conflict of interest between QFII and the major shareholders. In general, QFII shares between the major shareholders and small and medium investors. Once the company has a tunneling of big shareholder, there will be two parts of the loss of QFII. The first part is that if the big shareholder tunnel the listed companies, the interests of holdings will reduce, and the other part is that the other shareholders will sell the company's stock because of tunneling, and it will cause stock prices fell. Second, with the increase of the proportion of shares, the cost of "vote with the feet" will increase. QFII also has enough capacity to curb the big shareholder's tunneling behavior. As a professional institutional investor, QFII has a lot of advantages, such as using their own network of contacts to obtain more information, relying on professional investment team to make scientific and rational investment decisions, holding more shares to get more voice, and its deterrent and unique herding effect. In addition, QFII can monitor the emptiness of large shareholders in the following four ways: private negotiations, be into the board, submitting a shareholder motion, and fighting for the right to vote. Thus, the following assumptions are obtained:

- Hypothesis 1: A listed company with an investment of qualified foreign institutional investor (QFII) is less likely to be tunneled.

- Hypothesis 2: The proportion of holdings of qualified foreign institutional investors (QFII) is negatively correlated with the tunneling of large shareholders.

\subsection{QFII and Tunneling in the Companies with Different Ownerships}

Different types of major shareholders have different intention and different ability of tunneling. Shleifer and Wolfenzon found that the company's ownership arrangements affect the ability and motivation of large shareholders to encroach on corporate resources [22].

In theory, state-owned enterprises owned by all citizens, and the central government is an agent to manage state-owned enterprises. However, due to the limited energy of central government, most of the state-owned enterprises are en- 
trusted to local government to manage. Generally speaking, the ultimate controller of state-owned listed companies is the central government or local government. State-owned enterprises left the non-core assets to the parent company when it was in the divestiture of non-performing assets in the process of listing. So that the parent company and the listed company have a business link more or less. The parent company needs the support of the listed company. Moreover, the major shareholders and local governments have a strong willingness and sufficient capacity to transfer profits from listed companies. But such enterprises are more concerned about the degree of completion of political objectives than the profitability of the business. Such companies are economically viable, and they may do harm to the interests of small and medium shareholders due to some of its political goals.

China's private companies are the main way to solve the employment problem, an important source of tax revenue and the backbone of foreign trade. The private companies have the tunneling of large shareholders against two reasons. On the one hand, some companies brought a shell for listing. This approach determines the natural relationship between the listed company and the controlling shareholder. it is impossible to avoid the sale of products or services or other such related party transactions. On the other hand, private enterprises are generally individual or family-owned, and the prevalence of high concentration of equity phenomenon in such companies. The controlling shareholders in it often use control for their own interests to seek income, so they are more willing to occupy the interests of small and medium shareholders. Moreover, comparing with state-owned enterprises this type of company do not have strong financing capacity, and often make the use of pyramid ownership structure, cross-shareholding, mutual directors and other methods to use the control of cash flow to obtain more control.

Institutional economics theory holds that government governance and corporate governance are complementary to the constraints of controlling shareholders' tunneling behavior. In the market with weak government governance, the corporate governance mechanism will play an important role. With the deepening of state-owned enterprise reform, information disclosure in the state-owned enterprise is more transparent than in the family business, and the rules and regulations in it are more perfect. So that QFII can collect more information about state-owned enterprises. While the management of private enterprises is based on the relationship between the family members and the relationship between family and other companies, so the information is easily hidden. And more related transactions occurred because of the relationship between members. Therefore, QFII will meet more difficulty to detect the nature of private enterprises through the transaction. Moreover, because the transparency of information of foreign companies is not as high as state-owned enterprises, so it is more difficult to access to the information. The government plays the supervision and implementation roles of state-owned enterprises, while the government plays only supervision role of private enterprises and foreign-funded enterprises. 
Therefore, government governance is more effective in state-owned enterprises than in private enterprises and foreign-funded enterprises. QFII supervision of major shareholder behavior is a kind of corporate governance. Therefore, we get the following assumptions:

- Hypothesis 3: QFII can effectively curb the infringement of the interests of small and medium-sized shareholders in private enterprises and foreignfunded enterprises, but it is difficult to curb the infringement of the interests of small and medium-sized shareholders in state-owned enterprises.

\section{Empirical Research Design}

\subsection{Data Sources}

In this article we takes the A-share listed companies from 2012 to 2015 as the initial sample and filters the samples according to the following criteria:

- Eliminate the financial industry listed companies;

- Eliminate ST, PT listed companies;

- Eliminate the companies with the proportion of shares of the largest shareholder is less than $20 \%$;

- Eliminate samples with incomplete information and missing part.

After the above treatment, we have the panel data of samples of 1681 companies in 4 years. All the empirical data are from the WIND information database, and the statistical software used in this article is Stata12.0. As the annual report of China's listed companies in 2016 mostly published in April 2017, so we choose the non-financial listed companies in the A-share market as a sample from 2012 to 2015. WIND is a leading financial data, information and software service provider in China, and Wind database is a most complete and most accurate large-scale financial engineering and financial data warehouse with financial securities data as the core.

\subsection{Variable Selection}

- Explain variables: The tunneling of the largest shareholder (OCC). Because the tunneling behavior of the controlling shareholder is difficult to be observed through the observation, the scholars put forward different methods in order to measure the major shareholders' tunneling. In this article we use the "other receivables ratio" to measure the tunneling of large shareholders. In general, corporate receivables arising from non-purchase and sale activities are reflected in other receivables. In the annual report of listed companies, other receivables also account for the occupation of the company's funds by large shareholders. Of course, in addition to the occupation of large shareholders, other receivables of non-purchase and sale activities are also included in other receivables. But in general these funds can be recovered in the short term, while the occupation of large shareholders often can not be recovered. As a result, other receivables can be used to directly measure invasions of large shareholders. We record other receivables ratio as OCC, which 
means the occupation of large shareholders using to measure the tunneling.

$$
\text { OCC }=\frac{\text { other receivables }}{\text { total assets }} \text {. }
$$

- Explain variables: This article introduces two variables to measure the holdings of QFII. The first measures whether there are holdings of QFII, recorded as DQFII. DFQII for the dummy variable. When the QFII holdings of the average annual amount is bigger than zero DQFII $=1$, which presents in the previous year there are QFII holding the company's stock. While, when the QFII holdings of the average annual amount is smaller than zero DQFII $=0$, which presents in the previous year there are not QFII holding the company's stock. The second represents annual average shareholding ratio of QFII, recorded as AQFII. AQFII is a simple average of the QFII holdings in the quarterly report, which indicates the average shareholding ratio of QFII in that year. In addition, because of the endogenous issues between the tunneling of big shareholders and shareholdings of QFII, and I believe that QFII holdings have a lagging effect on the suppression of the tunneling of major shareholders. Therefore, we take the lagged one of the relevant variables into the model.

- Control variables: equity concentration (SHARE), audit opinion (AUDIT), asset-liability ratio (LEV), return on assets (ROA), company size (ASSET), and we also control year. In the above control variable, equity concentration is the proportion of the largest shareholder. The audit opinion is a dummy variable, and when the audit opinion in the annual report is unqualified opinion $\mathrm{AUDIT}=0$, otherwise AUDIT $=1$. And we take the lagged one into the model.

\subsection{Model Design}

In this paper we examined the balance panel data for 3 years of 1681 listed companies by $\mathrm{F}$ test and Hausman test, and finally determined to use the fixed effect model. The model is as follows:

$$
\mathrm{OCC}=\alpha_{i}+b_{1} \mathrm{QFII}+b \text { Control }_{i t}+\varepsilon_{i t}
$$

In Equation (2) QFII represents DQFII or AQFII, and Control it $_{\text {represents }}$ Control variables. In this article, we first plans to examine whether there is QFII investment can make effect on the tunneling of large shareholders. And then we selected the samples with QFII investment to study the impact of QFII shareholding ratio on large shareholders tunneling. Finally, the listed companies with QFII investment are further divided into state-owned enterprises, private enterprises and foreign-funded enterprises, and then we try to find the impact of QFII on large shareholders tunneling in the different types of listed companies.

\section{Empirical Results and Analysis}

\subsection{Descriptive Statistics and Correlation Analysis}

In Table 1, each variable has three rows. The first row is the total, recorded as $\mathrm{T}$ group. The second row represents the situation of listed companies with QFII 
Table 1. The main variable descriptive statistics.

\begin{tabular}{|c|c|c|c|c|c|c|}
\hline Variable & & Obs & Mean & Std. Dev. & Min & Max \\
\hline \multirow{3}{*}{ OCC } & $\mathrm{T}$ & 6724 & 0.0154 & 0.0291 & 0.0000 & 0.9932 \\
\hline & A & 1180 & 0.0140 & 0.0207 & 0.0000 & 0.2647 \\
\hline & B & 5544 & 0.0158 & 0.0306 & 0.0000 & 0.9932 \\
\hline \multirow{3}{*}{ AQFII } & $\mathrm{T}$ & 6724 & 0.1162 & 0.4983 & 0.0000 & 11.6335 \\
\hline & A & 1180 & 0.6623 & 1.0267 & 0.0144 & 11.6335 \\
\hline & B & 5544 & - & - & - & - \\
\hline \multirow{3}{*}{ SHARE } & $\mathrm{T}$ & 6724 & 39.9786 & 13.2927 & 20.0000 & 89.9900 \\
\hline & A & 1180 & 42.2795 & 14.2675 & 20.0000 & 88.5500 \\
\hline & B & 5544 & 39.4888 & 13.0249 & 20.0000 & 89.9900 \\
\hline \multirow{3}{*}{ AUDIT } & $\mathrm{T}$ & 6724 & 0.0186 & 0.1351 & 0.0000 & 1.0000 \\
\hline & A & 1180 & 0.0085 & 0.0917 & 0.0000 & 1.0000 \\
\hline & $\mathrm{B}$ & 5544 & 0.0207 & 0.1425 & 0.0000 & 1.0000 \\
\hline \multirow{3}{*}{ LEV } & $\mathrm{T}$ & 6724 & 42.0560 & 21.2379 & 1.0269 & 106.6952 \\
\hline & A & 1180 & 43.3537 & 21.0612 & 2.4640 & 97.1741 \\
\hline & $\mathrm{B}$ & 5544 & 41.7799 & 21.2670 & 1.0269 & 106.6952 \\
\hline \multirow{3}{*}{ ASSET } & $\mathrm{T}$ & 6724 & 22.0761 & 1.3091 & 17.0185 & 28.5087 \\
\hline & A & 1180 & 22.6930 & 1.4845 & 19.3051 & 28.5087 \\
\hline & B & 5544 & 21.9448 & 1.2295 & 17.0185 & 28.4052 \\
\hline \multirow{3}{*}{ ROA } & $\mathrm{T}$ & 6724 & 5.9862 & 6.2448 & -45.3813 & 106.1689 \\
\hline & A & 1180 & 7.0822 & 6.4573 & -41.6990 & 45.7550 \\
\hline & B & 5544 & 5.7529 & 6.1742 & -45.3813 & 106.1689 \\
\hline
\end{tabular}

Note: The value is the result of keeping four decimal places.

holdings, which are recorded as A group. The third row represents the situation of listed companies with non-QFII holdings, which are recorded as B group. As can be seen from Table 1, the average degree of the largest shareholder tunneling in China is $1.54 \%$; the degree of tunneling in the listed companies with QFII investment is $1.4 \%$, and it is smaller than which in the listed companies with non-QFII investment. From the perspective of the average shareholding of QFII, the average value of companies with QFII investment is $0.6632 \%$. Combined with its standard deviation, the proportion of QFII holdings among companies is really different and the shareholding ratio is low.

Table 2 is the correlation coefficient table of the main statistical variables. The table shows that the correlation coefficient between the main variables are less than 0.7 , that means there will be no multiple collinearity in the established regression equation. If there are multiple collinearity between variables, the effect of a single argument is measured inaccurate. 
Table 2. Correlation analysis of the main statistical variables.

\begin{tabular}{cccccccc}
\hline & OCC & SHARE & AUDIT & LEV & ASSET & ROA & AQFII \\
\hline OCC & 1 & & & & & & \\
SHARE & $0.065^{* * *}$ & 1 & & & & & \\
AUDIT & $-0.162^{* * *}$ & $-0.038^{* * *}$ & 1 & & & & \\
LEV & $0.169^{* * *}$ & $0.070^{* * *}$ & $-0.085^{* * *}$ & 1 & & & \\
ASSET & -0.00100 & $0.276^{* * *}$ & $0.062^{* * *}$ & $0.525^{* * *}$ & 1 & & \\
ROA & $-0.080^{* * *}$ & $0.046^{* * *}$ & $0.131^{* * *}$ & $-0.242^{* * *}$ & $0.042^{* * *}$ & 1 & \\
AQFII & $-0.022^{*}$ & $0.034^{* * *}$ & 0.0190 & -0.0180 & $0.089^{* * *}$ & $0.100^{* * *}$ & 1 \\
\hline
\end{tabular}

Note: ${ }^{*}$ means having significant correlation at 0.1 level; ${ }^{* *}$ means at 0.05 level; ${ }^{* * *}$ means at 0.01 level.

\subsection{Empirical Results}

Table 3 shows the regression results of the relationship between QFII and large shareholders tunneling. From the regression results (1), the degree of tunneling in the listed companies with QFII holdings is lower than it in the listed companies without QFII holdings, QFII holdings can significantly inhibit the tunneling of large shareholders at $5 \%$ level. Thus, hypothesis 1 is valid. Indeed the tunneling of the major shareholders of listed companies is reduced due to QFII holdings.

From the regression results (2), among the companies with QFII shares, the tunneling of major shareholders has a significant negative correlation with the annual shareholding ratio of QFII at 10\%, and when QFII annual shareholding ratio add $1 \%$ for each, the degree of tunneling of largest shareholders in the listed company will drop $0.00089 \%$. Therefore, the hypothesis 2 proved. In addition, although QFII can significantly reduce the degree of tunneling of large shareholders, but the extent of the reduction is not too much, which may be required for the holding ratio of single QFII for a single stock not more than $10 \%$.

The result of regression (3) is the regression result of QFII and the tunneling of large shareholders in state-owned enterprises. The result of regression (4) is in private enterprises, and the result of regression (5) is in foreign-funded enterprises. Compared with the results of these three regressions, it can be seen that there is a significant negative correlation between the shareholding ratio of QFII and tunneling of the biggest shareholder in state-owned enterprises and private enterprises at the level of $10 \%$. From the perspective of regression coefficient, if QFII annual average shareholding ratio add $1 \%$ for each, the degree of the largest shareholder's tunneling in the state-owned enterprises will drop $0.000838 \%$, While in the private enterprises it will drop $0.00112 \%$. That means the degree of inhibition of QFII shareholding ratio in the private companies is higher than which in the state-owned companies. However, in the foreign-funded enterprises QFII annual shareholding ratio and large shareholders tunneling is positive correlation, but not significant. The explanation may be QFII do not having enough information for foreign-funded enterprises, and QFII having a small shareholding ratio, then it failed to play an effective role in the suppression of 
Table 3. Regression results

\begin{tabular}{|c|c|c|c|c|c|}
\hline & \multirow[b]{2}{*}{ Total } & \multirow{2}{*}{$\begin{array}{l}\text { With QFII } \\
\text { holdings }\end{array}$} & \multicolumn{3}{|c|}{ Different types of companies with QFII holdings } \\
\hline & & & $\begin{array}{l}\text { State-owned } \\
\text { Enterprises }\end{array}$ & $\begin{array}{c}\text { Private } \\
\text { Enterprise }\end{array}$ & $\begin{array}{l}\text { Foreign-funded } \\
\text { Enterprises }\end{array}$ \\
\hline & (1) & (2) & (3) & $(4)$ & (5) \\
\hline Variable & OCC & OCC & OCC & OCC & OCC \\
\hline DQFII & $\begin{array}{c}-0.000721^{* *} \\
(0.000212)\end{array}$ & & & & \\
\hline AQFII & & $\begin{array}{l}-0.000890^{\star} \\
(0.000298)\end{array}$ & $\begin{array}{l}-0.000838^{\star} \\
(0.000343)\end{array}$ & $\begin{array}{l}-0.00112^{\star} \\
(0.000402)\end{array}$ & $\begin{array}{c}0.000117 \\
(0.000306)\end{array}$ \\
\hline SHARE & $\begin{array}{l}-0.000191^{*} \\
(8.10 \mathrm{e}-05)\end{array}$ & $\begin{array}{l}-0.000664^{*} \\
(0.000210)\end{array}$ & $\begin{array}{l}7.04 \mathrm{e}-05^{*} \\
(2.71 \mathrm{e}-05)\end{array}$ & $\begin{array}{l}-0.00125^{\star} \\
(0.000512)\end{array}$ & $\begin{array}{l}-6.55 e-05 \\
(3.84 e-05)\end{array}$ \\
\hline AUDIT & $\begin{array}{l}-0.0183^{\star *} \\
(0.00430)\end{array}$ & $\begin{array}{l}-0.00718 \\
(0.00777)\end{array}$ & $\begin{array}{l}-0.00252 \\
(0.00744)\end{array}$ & $\begin{array}{c}0 \\
(0)\end{array}$ & $\begin{array}{c}-0.00874^{* *} \\
(0.00230)\end{array}$ \\
\hline LEV & $\begin{array}{l}0.000354^{* * *} \\
(4.15 \mathrm{e}-05)\end{array}$ & $\begin{array}{c}4.10 \mathrm{e}-05 \\
(5.37 \mathrm{e}-05)\end{array}$ & $\begin{array}{l}0.000228^{* *} \\
(4.01 \mathrm{e}-05)\end{array}$ & $\begin{array}{l}-0.000148 \\
(0.000127)\end{array}$ & $\begin{array}{l}0.000242^{\star * *} \\
(3.42 \mathrm{e}-05)\end{array}$ \\
\hline ASSET & $\begin{array}{c}-0.00739^{\star *} \\
(0.00181)\end{array}$ & $\begin{array}{l}-0.00302 \\
(0.00176)\end{array}$ & $\begin{array}{l}0.000472 \\
(0.000445)\end{array}$ & $\begin{array}{l}-0.00970 \\
(0.00420)\end{array}$ & $\begin{array}{c}-0.00463^{\star *} \\
(0.00117)\end{array}$ \\
\hline ROA & $\begin{array}{l}0.000770^{* * *} \\
(0.000118)\end{array}$ & $\begin{array}{c}0.000236 \\
(0.000169)\end{array}$ & $\begin{array}{l}0.000318^{*} \\
(0.000104)\end{array}$ & $\begin{array}{c}0.000530 \\
(0.000566)\end{array}$ & $\begin{array}{c}0.000130 \\
(8.26 \mathrm{e}-05)\end{array}$ \\
\hline Constant & $\begin{array}{l}0.166^{* *} \\
(0.0362)\end{array}$ & $\begin{array}{c}0.107^{\star} \\
(0.0423)\end{array}$ & $\begin{array}{l}-0.0146 \\
(0.00769)\end{array}$ & $\begin{array}{l}0.273^{\star} \\
(0.110)\end{array}$ & $\begin{array}{l}0.104^{\star *} \\
(0.0248)\end{array}$ \\
\hline Observations & 6,724 & 1,180 & 637 & 459 & 43 \\
\hline R-squared & 0.165 & 0.031 & 0.052 & 0.109 & 0.355 \\
\hline Number of groups & 1,681 & 653 & 332 & 276 & 22 \\
\hline
\end{tabular}

Note: ${ }^{\star}$ means having significant correlation at 0.1 level; ${ }^{* *}$ means at 0.05 level; ${ }^{* * *}$ means at 0.01 level.

the tunneling of the largest shareholder in foreign-funded enterprises. To sum up, in the state-owned enterprises and private enterprises corporate governance and government governance complementary relationship has been fully reflected. But foreign-funded enterprises and state-owned enterprises did not reflect that similar relationship. This may because the government supervision of foreign-funded enterprises is more stringent, and QFII have less information about foreign-funded enterprises. Therefore, hypothesis 3 is not fully certified.

In addition, external auditing has a significant inhibitory effect on the tunneling of large shareholders in the foreign-funded enterprises, but this inhibition does not exist in private enterprises. The size of the company in private and foreign-funded enterprises has a negative correlation with the tunneling of large shareholders, but in the state-owned enterprises it has a positive correlation. It 
shows that public concern caused by the increase of corporate assets will inhibit the tunneling of large shareholders in the private enterprises and foreign-funded enterprises.

\section{Conclusions and Suggestion}

This article took all the A-shares of the Shanghai Stock Exchange and Shenzhen Stock Exchange from 2012 to 2015 as the samples. Depending on exclude conditions, finally left the 1681 companies as the object of study, used to study the relationship between QFII holdings and tunneling of the substantial shareholders in the listed companies, and the results show: 1) QFII holdings can reduce the degree of tunneling of the substantial shareholders effectively, and control the behavior of substantial shareholders' tunneling. 2) The relationship between the shareholding ratio of QFII and the degree of substantial shareholders' tunneling appeared negative correlation obviously. 3) In the different ownership companies, QFII has different inhibition on substantial shareholders' tunneling. In private enterprises and state-owned enterprises, QFII can take the adverse effect, and the adverse effect on the private enterprises is superior to state-owned enterprises, but it can not take the adverse effect on foreign-funded enterprises.

According to the above conclusions, we make the following proposal: firstly, complete the timeliness, quality and quantity of the information disclosure. In order to improve the timeliness of the information disclosure, we should decrease the time-lag of annual reports. In order to improve the quality and quantity of information, we need a good audit environment to keep the independence of external audit. Secondly, increase the limitation of single stock holding of single QFII gradually. Since established China's QFII institution, this institution has relaxed constantly, but the limitation of each QFII holding a listed company has not changed, it is partly dampened the enthusiasm of QFII which participating in corporate governance and the voice of QFII on the shareholders meeting, so relaxing the rules appropriately by a reasonable foundation in the future. Thirdly, to strengthen the propaganda of Chinese investors' scientific investment concept. Although QFII has the style of value investing, it is thought to keep the long-term holdings in the environment of China's speculation, reducing the degree of the QFII participating in corporate governance. But, we need to do a good job in publicity of the idea of value investment, decrease the opportunistic practice of domestic investors, provide good market environment for the entrance of QFII, and play a role of QFII adequately.

\section{References}

[1] Hartzell, J.C. and Starks, L.T. (2003) Institutional Investors and Executive Compensation. The Journal of Finance, 58, 2351-2374. https://doi.org/10.1046/j.1540-6261.2003.00608.x

[2] Smith, M.P. (1996) Shareholder Activism by Institutional Investors: Evidence from CalPERS. The Journal of Finance, 51, 227-252. 
https://doi.org/10.1111/j.1540-6261.1996.tb05208.x

[3] Chen, X., Harford, J. and Li, K. (2007) Monitoring: Which Institutions Matter? Journal of Financial Economics, 86, 279-305.

[4] Coffee, J.C. (1991) Liquidity versus Control: The Institutional Investor as Corporate Monitor. Columbia Law Review, 91, 1277-1368. https://doi.org/10.2307/1123064

[5] Bushee, B.J. (1998) The Influence of Institutional Investors on Myopic R \& D Investment Behavior. Accounting Review, 73, 305-333.

[6] Rama, S. and Yu, Y. (2012) Institutional Ownership and Conservatism. Journal of Accounting \& Economics, 53, 98-114.

[7] Tang, S.L. and Yuan, C.S. (2010) Supervision or Seizure: A Study on the Role of Institutional Investor Governance-Empirical Evidence from China's Capital Market. Manage Comments, 22, 19-29.

[8] Zheng, G.J. (2009) Research on the Relationship between Connected Transactions and Earnings Quality Based on Efficiency View and Excavation. Accounting Research, 10, 68-76.

[9] Yao, Y. and Liu, Z.Y. (2009) Are Institutional Investors Supervising? Financial Research, 6, 128-143.

[10] Wu, X.C., Zhang, J. and Hu, Z.Y. (2016) The Characteristics of Institutional Investors, the Ultimate Nature of the Controller and the Tunneling of Large Shareholders: Research on the Perspective of Connected Transactions. Foreign Economy and Management, 6, 3-20.

[11] Sun, L. and Lin, L. (2006) An Empirical Analysis of QFII Investment in Mainland China Stock Market. Financial Research, 7, 123-133.

[12] Hou, P.P. (2009) Comparison of Investment Behavior between QFII and China's Securities Investment Funds. Shanghai Jiaotong University, Shanghai.

[13] Shen, W.T. and Zhu, G.D. (2011) Qualified Foreign Institutional Investors Excess Rate of Return and Small and Medium Investors "Protection-Based on the Perspective of Small and Medium Investors" Investment Strategy. Economic Management, 7, 160-166.

[14] Teng, L.L. and Huang, C.L. (2012) A Study on the Characteristics of QFII Shareholding in China-An Empirical Analysis Based on Stock Preference and Stock Period. Investment Research, 10, 84-97.

[15] Batra, A. (2004) Stock Return Volatility Patterns in India. General Information.

[16] Gao, Z.D. (2008) An Empirical Study on the Influence of QFII on China's Stock Market: A Test Based on Cointegration and Granger Causality. World Economic Situation, 4, 14-17.

[17] Liu, C.Y., Hu, F. and Wang, H. (2007) Does QFII Also Have Herd Behavior? Financial Research, 10, 111-122.

[18] Wei, Y.T. (2014) Analysis on the Impact of QFII Investment Behavior on the Stability of China's Securities Market. Journal of Hubei University of Economics ( $\mathrm{Hu}$ manities and Social Sciences), 12, 53-55.

[19] Dong, X.F. (2007) Research on QF and Governance of Listed Companies in China. Zhejiang University, Hangzhou.

[20] Ye, D. (2009) Research on the Correlation between QFII Shareholding and the Performance of Listed Companies. Accounting Monthly, 9, 87-89.

[21] Wu, W.H. and Wan, D.F. (2012) QFII Shareholding and Cash Dividend Policy of Listed Companies-Evidence from Chinese A-Share Listed Companies from 2008 
to 2011. Journal of Shanxi Finance and Economics University, 11, 51-58.

[22] Shleifer, A. and Wolfenzon, D. (2002) Investor Protection and Equity Markets. Journal of Financial Economics, 66, 3-27.

Submit or recommend next manuscript to SCIRP and we will provide best service for you:

Accepting pre-submission inquiries through Email, Facebook, LinkedIn, Twitter, etc. A wide selection of journals (inclusive of 9 subjects, more than 200 journals) Providing 24-hour high-quality service User-friendly online submission system Fair and swift peer-review system Efficient typesetting and proofreading procedure Display of the result of downloads and visits, as well as the number of cited articles Maximum dissemination of your research work

Submit your manuscript at: http://papersubmission.scirp.org/ Or contact ajibm@scirp.org 